\title{
Recombinant gp19 as a potential antigen for detecting anti-Ehrlichia canis antibodies in dog sera
}

\author{
gp19 recombinante como um antígeno potencial para detecção de anticorpos \\ anti-Ehrlichia canis em soros de cães \\ Rômulo Silva de Oliveira ${ }^{1}$; Rodrigo Casquero Cunha² ; Jonas Moraes-Filho ${ }^{3}$; \\ Relber Aguiar Gonçales ${ }^{4}$; Ana Paula de Souza Stori de Lara ${ }^{1}$; Luciana Farias da Costa de Avila ${ }^{1}$; \\ Marcelo Bahia Labruna ${ }^{3}$; Fábio Pereira Leivas Leite ${ }^{2 *}$
}

\begin{abstract}
${ }^{1}$ Departamento de Microbiologia e Parasitologia, Universidade Federal de Pelotas - UFPel, Pelotas, RS, Brasil
${ }^{2}$ Centro de Desenvolvimento Tecnológico, Universidade Federal de Pelotas - UFPel, Pelotas, RS, Brasil

${ }^{3}$ Faculdade de Medicina Veterinária e Zootecnia, Universidade de São Paulo - USP, São Paulo, SP, Brasil

^Pós-graduação em Biologia Celular e Molecular, Universidade de São Paulo - USP, São Paulo, SP, Brasil

Received January 28, 2015

Accepted May 13, 2015
\end{abstract}

\begin{abstract}
The canine monocytic ehrlichiosis, caused by Ehrlichia canis, is endemic in several regions of Brazil. Some serological diagnostic techniques using immunodominant proteins of $E$. canis as antigens are available, but their specificities and sensitivities are questionable. Based on this, the objective of this study was to test the antigenic potential of the recombinant gp19 protein (rGP19) for subsequent use in diagnostic tests. The rGP19 expressed in the Escherichia coli strain BL21 (DE3) C41 was recognized in the sera from experimentally infected dogs using ELISA and Western blotting. Thus, it was possible to obtain a promising antigen with the ability to differentiate between $E$. canis-positive and -negative animals, even 1 week after infection.
\end{abstract}

Keywords: Diagnosis, serology, rickettsiae, ehrlichiosis.

\section{Resumo}

A erliquiose monocítica canina, causada por Ehrlichia canis, é uma doença endêmica em diversas regióes do Brasil. Algumas técnicas de diagnóstico sorológico, utilizando proteínas imunodominantes de E. canis como antígenos, estão disponíveis, porém suas especificidades e sensibilidades são questionáveis. Com base nesse fato, o objetivo deste trabalho foi testar o potencial antigênico da proteína GP19 recombinante (rGP19) para posterior utilização em testes diagnósticos. A rGP19, expressa em E. coli cepa BL21 (DE3) C41, foi reconhecida por soros de cães experimentalmente infectados pelas técnicas de ELISA e Western blotting. Dessa maneira, conseguiu-se obter um antígeno promissor com a capacidade de diferenciar animais positivos de negativos, até mesmo uma semana após a infecção.

Palavras-chave: Diagnóstico, sorologia, rickettsias, ehrliquiose.

\section{Introduction}

Ehrlichia canis, the causative agent of canine monocytic ehrlichiosis (CME), is a pleomorphic Gram-negative obligate intracellular bacterium that primarily infects the leukocytes (mainly monocytes) of domestic dogs (COHN, 2003; HUXSOLL et al., 1970). This micro-organism has a worldwide distribution, but it is especially found in warm temperate and tropical areas; it is likely to be transmitted between dogs by arthropod vectors, particularly

*Corresponding author: Fábio Pereira Leivas Leite. Centro de Desenvolvimento Tecnológico - CDTEC, Biotecnologia, Campus Capão do Leão, Universidade Federal de Pelotas - UFPel, prédio 19, Corredor da Embrapa, s/n, Capão do Leão, CEP 96160-000, Pelotas, RS, Brasil. e-mail: fabio@leivasleite.com.br ticks of the species Rhipicephalus sanguineus sensu lato (WOODY \& HOSKINS, 1991).

The transmission of CME occurs during the tick blood meal from an infected dog; the tick can transmit the infection to another dog during a new blood meal. E. canis is transmitted through the salivary secretions that were contaminated during the tick bite, which were phagocytosed by mononuclear cells, where the micro-organisms subsequently replicate by binary fission. Larval and nymphal ticks become infected when they feed on a dog in the acute phase of the disease by ingesting infected leukocytes. Within the tick, E. canis is disseminated by hemocytes from the intestine to the salivary glands (DAGNONE et al., 2003). 
The CME has high rates of global prevalence, as shown by international serological surveys conducted in different populations of dogs. In these surveys, it was found that $78 \%$ of dogs in Senegal (PARZY et al., 1991), 68\% in Tunisia (BROUQUI et al., 1991), 66.7\% in Spain (SAINZ et al., 1995), 41\% in Egypt (BOTROS et al., 1995), $30 \%$ in Israel (BANETH et al., 1996), 10.8\% in the American state of Oklahoma (MURPHY et al. 1998), and 2.2\% in Switzerland (PUSTERLA et al., 1998), showed anti-E. canis antibodies.

In Brazil, several seroprevalence studies have been performed and have demonstrated different infection rates depending on the geographic location and the diagnostic method used (VIEIRA et al., 2011). Using an indirect immunofluorescence assay (IIFA), the seroprevalence rates in dogs were found to range from 4.8 to $42.5 \%$ in the Rio Grande do Sul (SAITO et al., 2008) and Mato Grosso (SILVA et al., 2010) states, respectively. Using a commercially available immunoenzymatic dot-enzyme-linked immunosorbent assay (ELISA) (SNAP ${ }^{\circledR} 3 \mathrm{DX}$, IDEXX Laboratories Inc., Portland, ME, USA) to test random populations, prevalence rates were found to range from 1.7 to $54.5 \%$ in dogs from the Rio Grande do Sul and Pernanbuco states, respectively (LABARTHE et al., 2003). Despite this finding, there are still some states where prevalence data do not exist.

The diagnosis of CME can be performed by detecting specific antibodies in the serum of animals or by identifying parasites in blood smears. Sensitive and specific molecular techniques were evaluated for the detection of antigens, but they are not yet available for use in routine diagnostics due to their high costs (CADMAN et al., 1994; NAKAGHI et al., 2010; WANER et al., 1998).

E. canis is rarely identified in cytology samples and its intracytoplasmic inclusions or morulae appear more frequently in the acute phase of the disease, which are phases characterized by mild clinical signs (DAGNONE et al., 2003). The definitive diagnosis is made based on the finding of inclusions in the peripheral blood mononuclear cells of infected animals; however, it is sometimes difficult to demonstrate the typical form of the morula because the parasite is present in small numbers in the blood, and this could lead to false-negative results (DAGNONE et al., 2003; RIKIHISA, 1991).

Bélanger et al. (2002) compared four methods of serological detection for the diagnosis of CME. The authors determined that indirect immunofluorescence assay (IIFA) was the best, but most expensive, method for zoonotic control in an urban area with a large number of animals.

Clinical suspicion of CME can be confirmed by identifying the causative organism in smears of peripheral blood leukocytes, leukocyte cover, and in cytological samples of the lungs, lymph nodes, spleen, or bone marrow using serological methods such as IIFA. CME can also be confirmed via imported diagnostic kits including dot-ELISA (Immunocomb@) or ELISA (SNAP@ 3DX); immunoblot assays; molecular biology techniques such as polymerase chain reaction (PCR), which can be nonspecific depending on the sample used; and cell culture, which is a method that is used less frequently (NAKAGHI et al., 2010).

Therefore, there is a need for a sensitive and specific diagnostic test that can prematurely identify the presence of the agent in biological fluids. This test should also be able to identify and reliably diagnose animals that are infected with CME, thus enabling the implementation of swift and appropriate control measures.

A total of eight major immunoreactive proteins were recognized by antibodies in convalescent-phase sera 6 weeks after inoculation. The antibody response to the proteins in the p28/p30 multigene family, major outer membrane proteins, developed 2 weeks later compared with other two proteins of approximately 19 and $37 \mathrm{kDa}$ (glycoproteins gp19 and gp36), which were found to elicit the earliest acute-phase antibody response (McBRIDE et al., 2003).

Previous studies have showed gp19 and gp36 E. canis major immunoreactive antigens as dominant targets of the early host antibody response (McBRIDE et al., 2003) and thus are high-priority targets for serological diagnostic techniques development. Several other glycoproteins have been identified in Ehrlichia species (DOYLE et al., 2006). A commercially available ELISA (SNAP@ 3DX) for the diagnosis of CME has been developed, which is based on antibody reactivity to two E. canis $\mathrm{p} 30$ peptides, but its sensitivity with sera containing low antibody titers $(<320)$ remains questionable (BELÁNGER et al., 2002).

The glycoprotein gp19 is an highly conserved outer membrane protein, probably secreted extracellularly, which has a potential role in adhesion and internalization to host cells (DOYLE et al., 2006; FERREIRA et al., 2014; McBRIDE et al., 2007). Because its immunogenicity and the presence of antibodies anti-gp19 in the first week of infection, we aimed to develop and characterize the E. canis gp19 recombinant antigen that could be used for the diagnosis of CME.

\section{Materials and Methods}

\section{Canine sera}

To perform serological tests, we used the sera from three dogs (beagles) that were experimentally infected with the $E$. canis strain Jaboticabal, which was harvested weekly from the day before the infection to the ninth or tenth week after infection (MORAES-FILHO, 2013). These sera were provided by the Departamento de Medicina Veterinária Preventiva e Saúde Animal from the Universidade de Sáo Paulo (USP) and were previously tested by IIFA, presenting different titers of antibody against E. canis (from negative to 1:40,960).

\section{DNA extraction, amplification, and cloning}

The E. canis Jaboticabal strain was cultivated in DH82 cells, as previously described (AGUIAR et al., 2008). A pellet containing $1 \mathrm{~mL}$ of $E$. canis-infected cell culture was submitted to DNA extraction using the DNeasy tissue kit (Qiagen N.V., Venlo, Netherlands), following the manufacturer's instructions. The total DNA extracted was eluted in $100 \mu \mathrm{L}$ of elution buffer and quantified in a spectrophotometer through its absorbance at $260 \mathrm{~nm}$ and $280 \mathrm{~nm}$ filters $\left(\mathrm{A}_{260 \mathrm{~nm}}\right.$ and $\left.\mathrm{A}_{280 \mathrm{~nm}}\right)$.

The $g p 19$ gene was amplified by PCR using primers constructed based on a sequence obtained from GenBank (accession number: EU118960). These primers were synthesized containing the following EcoRI and $K p n I$ restriction sites: forward 
(5'-GCGGTACCTAATGTTACACGTTCAAAAT-3') and reverse (5'-GCGAATTCTTACGCACAATCACAAC-3'). The PCR template and the pAE plasmid were restricted with EcoRI (New England Biolabs, Ipswich, MA, USA) and KpnI (New England Biolabs), and they were then submitted to ligation with T4 DNA Ligase (Promega Corporation, Madison, WI, USA), according to the manufacturer's protocol. The ligation product was used to transform the Escherichia coli strain TOP10F', and the transformed cells were selected on Luria Bertani (LB) media plates supplemented with ampicillin at $100 \mathrm{mg} \times \mathrm{mL}^{-1}$. The pAE plasmid containing the DNA sequence (nucleotides 1-414) of the $g p 19$ gene (pAE-gp19), without the stop codon, was extracted and sequenced to confirm the sequence and its frame with polyhistidine-tag. The plasmid pAE-GP19 was used to transform different $E$. coli protein expression strains, which were made chemically competent by thermal shock. The protein expression strains that were transformed included BL21 (DE3) Star, BL21 (DE3) codon Plus Ril, BL21 (DE3) Plyss, BL21 (DE3) C43 PAVD10, BL21 (DE3) Roseta gami B, BL21 (DE3) Roseta, BL21 (DE3) TRX, BL21 (DE3) codon Plus RP, BL21 (DE3) C41, BL21 (DE3) C43, and JM 109 (Invitrogen ${ }^{\circledR}$; Thermo Fisher Scientific, Waltham, MA, USA).

\section{Selecting the best expression strain}

A single colony of each transformed $E$. coli strain was grown in $5 \mathrm{~mL}$ of LB broth supplemented with ampicillin $\left(100 \mathrm{mg} \times \mathrm{mL}^{-1}\right)$ and, depending on the strain resistance, chloramphenicol $\left(50 \mathrm{mg} \times \mathrm{mL}^{-1}\right)$ in an orbital shaker $(200 \mathrm{rpm})$ at $37^{\circ} \mathrm{C}$ overnight (16-18 hours). Each culture was inoculated in a $125 \mathrm{~mL}$ Erlenmeyer flask with $20 \mathrm{~mL}$ of LB with ampicillin and/or chloramphenicol, to an optical density at $600 \mathrm{~nm}\left(\mathrm{OD}_{600 \mathrm{~nm}}\right)$ equal to 0.1 at $37^{\circ} \mathrm{C}$ and $200 \mathrm{rpm}$. When the $\mathrm{OD}_{600 \mathrm{~nm}}$ reached 0.8 , expression was induced by adding two different concentrations of IPTG (isopropyl B-D-1-thiogalactopyranoside; $1 \mathrm{mM}$ or $3 \mathrm{mM})$. The expressions were maintained at three different temperatures $\left(37^{\circ} \mathrm{C}, 25^{\circ} \mathrm{C}\right.$, and $20^{\circ} \mathrm{C}$ ) and for two different times ( 4 hours and 16 hours). An aliquot containing $1 \mathrm{~mL}$ each of culture was collected every hour, centrifuged at $13,000 \times \mathrm{g}$ for 1 minute, and the cell pellets were then stored at $-20^{\circ} \mathrm{C}$. The cultures were centrifuged at $10,000 \times \mathrm{g}$ for 10 minutes at the end of the induction time to obtain the cell pellets, which were stored at $-20^{\circ} \mathrm{C}$, until their utilization.

The cell pellets containing $1 \mathrm{~mL}$ of induced culture were added to $100 \mu \mathrm{L}$ of $2 \times$ protein loader buffer (4\% sodium dodecyl sulfate, 20\% glycerol, 120 mM Tris-HCL, pH 6.8, 10\% 2-mercaptoethanol, and $0.3 \%$ Bromophenol Blue) and were incubated for 10 minutes at $99^{\circ} \mathrm{C}$ for protein denaturation. Aliquots containing $20 \mu \mathrm{L}$ of each sample were loaded into $12 \%$ sodium dodecyl sulfate-polyacrylamide gel electrophoresis (SDS-PAGE). The gels were stained with Coomassie Blue, or they were used to transfer the proteins to nitrocellulose membranes to perform Western blotting. The nitrocellulose membranes were blocked with $5 \%$ skimmed milk powder in phosphate buffered saline (PBS) at $37^{\circ} \mathrm{C}$ for 1 hour under stirring and were washed twice with PBS-T (PBS containing $0.1 \%$ Tween 20; pH 7.4) for 5 minutes. For the primary antibody, we used canine sera that were either positive or negative for CME, 1:500 in PBS, and mouse monoclonal anti-His (C-term) (Invitrogen ${ }^{\circledR}$; Thermo Fisher Scientific) 1:15,000, incubated for 1 hour at $37^{\circ} \mathrm{C}$. The membrane was washed twice with PBS-T and incubated with either peroxidase-conjugated rabbit anti-dog immunoglobulin (Ig)G secondary antibody (Sigma-Aldrich Co., St. Louis, MO, USA), diluted 1:5,000 in $\mathrm{PBS}$, or peroxidase-conjugated rabbit anti-mouse $\mathrm{IgG}$, diluted 1:6,000 in PBS-T, for 1 hour at $37^{\circ} \mathrm{C}$. The membranes were then washed three times with PBS-T. The protein bands were revealed using developing solution $(5 \mathrm{~mL}$ of Milli-Q water; $5 \mathrm{mg}$

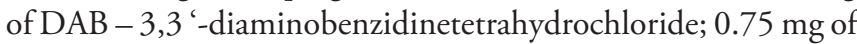
$\mathrm{NH}_{4}$ ) until well-defined bands (5-10 minutes) appeared on the nitrocellulose membrane, which was washed in sterile Milli-Q water and photo documented.

\section{rGP19 expression and purification}

SDS-PAGE and Western blotting determined that the best clone for rGP19 expression was BL21 (DE3) C41. A single colony of transformed BL21 (DE3) C41 was grown in $100 \mathrm{~mL}$ of LB broth supplemented with ampicillin $\left(100 \mu \mathrm{g} \times \mathrm{mL}^{-1}\right)$ in an orbital shaker $(200 \mathrm{rpm})$ at $37^{\circ} \mathrm{C}$ overnight (16-18 hours). The culture was then inoculated in a $2 \mathrm{~L}$ Erlenmeyer flask with $500 \mathrm{~mL}$ of LB with ampicillin to an $\mathrm{OD}_{600 \mathrm{~nm}}$ equal to 0.1 . When the $\mathrm{OD}_{600 \mathrm{~nm}}$ reached 0.8 , expression was induced by adding $1 \mathrm{mM}$ of IPTG. The expression was maintained for 16 hours at $25^{\circ} \mathrm{C}$. The cultures were centrifuged at the end of the induction time at $10,000 \times \mathrm{g}$ for 10 minutes to obtain the cell pellets, which were immediately utilized for purification.

The cell pellet obtained from the $500 \mathrm{~mL}$ induction was tested for solubilization. The pellet was eluted in $15 \mathrm{~mL}$ of Akta Wash $\left(\mathrm{NaH}_{2} \mathrm{PO}_{4} 0.234 \%, \mathrm{NaCl} 2.92 \%\right.$, and imidazole $0.068 \%$ ), then added of PMSF (phenylmethanesulfonyl fluoride, $1 \mathrm{mM})$ and $150 \mu \mathrm{L}$ of lysozyme $\left(10 \mathrm{mg} \mathrm{mL}^{-1}\right)$, and incubated for 1 hour at $4^{\circ} \mathrm{C}$. The suspension was sonicated for six cycles of 20 seconds at $60 \mathrm{~Hz}$ and then centrifuged at $10,000 \times \mathrm{g}$ for 10 minutes. The supernatant was saved and the pellet was washed three times with PBS and eluted with $15 \mathrm{~mL}$ of Akta Wash with N-lauroylsarcosine $\left(\mathrm{NaH}_{2} \mathrm{PO}_{4} 0.234 \%, \mathrm{NaCl} 2.92 \%\right.$, imidazole $0.068 \%$, and lauroyl sarcosine $0.2 \%$ ) under stirring for 48 hours at $4{ }^{\circ} \mathrm{C}$. The suspension was centrifuged again, the supernatant was saved, and the pellet was washed with PBS and eluted in $15 \mathrm{~mL}$ of Akta Wash with urea ( $\mathrm{NaH}_{2} \mathrm{PO}_{4} 0.234 \%, \mathrm{NaCl}_{2} .92 \%$, imidazole $0.068 \%$, and urea $0.36 \%$ ) under stirring for 48 hours at $4{ }^{\circ} \mathrm{C}$. The suspension was centrifuged again and the pellet and supernatant were separated and saved.

The pellets and supernatants of each step were subjected to $12 \%$ SDS-PAGE to check for rGP19 expression. Soluble recombinant protein was purified by affinity chromatography, where each Akta Wash supernatant (around $15 \mathrm{~mL}$ ) was applied through a $1 \mathrm{~mL}$ $\mathrm{Ni}$-Sepharose Hi Trap chelating column (GE Healthcare, Little Chalfont, UK), which was previously equilibrated with its respective solubilization buffer following the manufacturer's guidelines. The $\mathrm{Ni}^{+}$ column was washed with $5 \mathrm{~mL}$ of its respective Akta Wash, and the protein was eluted with aliquots containing $1 \mathrm{~mL}$ of elution buffer 
$\left(\mathrm{NaH}_{2} \mathrm{PO}_{4} 0.234 \%\right.$ and $\left.\mathrm{NaCl} 2.92 \%\right)$ with different concentrations of imidazole $(10 \%, 20 \%, 30 \%, 40 \%$, and 100\%). Fractions of 1 $\mathrm{mL}$ elution were collected. All flow-through portions were saved and applied to $12 \%$ SDS-PAGE. The elution fractions with the protein, confirmed by SDS-PAGE, were pooled and dialyzed at $4^{\circ} \mathrm{C}$ against PBS with $0.1 \%$ TritonX-100. The purified rGP19 was submitted to SDS-PAGE and Western blotting, as described above, and quantified by $\mathrm{A}_{280 \mathrm{~nm}}$; the means of the standard curve method with bovine serum albumin (BSA) on 12\% SDS-PAGE were also recorded. To serve as a positive control during Western blotting, we used $1 \mu \mathrm{g}$ of a $72 \mathrm{kDa}$ polyhistidine-tag protein that was previously purified.

\section{Indirect enzyme-linked immunosorbent assay (ELISA)}

To standardize the ELISA, 96-well polystyrene microtiter plates (PolySorp ${ }^{\text {TM }}$ Nunc; Thermo Fisher Scientific) were coated with $100 \mu \mathrm{L} /$ well of $50 \mathrm{mM}$ carbonate-bicarbonate buffer ( $\mathrm{pH} 9.6$ ) containing $50 \mathrm{ng}, 100 \mathrm{ng}$, or $150 \mathrm{ng}$ of rGP19 for 30 minutes at $4^{\circ} \mathrm{C}$. The plates were then washed three times with PBS-T and blocked using 5\% nonfat milk in PBS at $4^{\circ} \mathrm{C}$ for 1 hour under stirring. After three washes with PBS-T, $100 \mu \mathrm{L} /$ well of IIFA-positive and -negative canine sera, all in triplicate, were added at concentrations of 1:50, 1:100, 1:200, 1:400, and 1:800 in PBS and incubated at $37^{\circ} \mathrm{C}$ for 1 hour. After three washes with PBS-T, $100 \mu \mathrm{L} /$ well of anti-dog IgG peroxidase-conjugated antibody (Sigma-Aldrich Co.) were added, diluted at 1:6,000 in PBS, followed by incubation at $37^{\circ} \mathrm{C}$ for 1 hour. After another five washes, $100 \mu \mathrm{L} /$ well of the substrate $(50 \mathrm{mM}$ phosphate-citrate buffer containing $0.4 \mathrm{mg} \times \mathrm{mL}^{-1}$ of o-phenylenediaminedihydrochloride, and $0.04 \%$ hydrogen peroxide [v/v], $\mathrm{pH} 5.0$ ) were added to each well. The plates were incubated in the dark at room temperature for 15 minutes. Next, $50 \mu \mathrm{L} /$ well of stop buffer $\left(\mathrm{H}_{2} \mathrm{SO}_{4} 1 \mathrm{~N}\right)$ were then added to stop the reaction. The mean optical density at $492 \mathrm{~nm}\left(\mathrm{OD}_{492 \mathrm{~nm}}\right)$ was determined for all test wells using a microtiter plate reader (Multiskan ${ }^{\circledR}$ MCC/340 MKII; Titertek Instruments, Inc., Huntsville, AL, USA). A sample with a reading that was two standard deviations above the negative control absorbance peak was considered positive.

The ELISA of the sera from the experimentally infected dogs was performed, as described above, with $50 \mathrm{ng}$ of rGP19 per well and sera dilution of 1:100. For the ELISA intraplate control, we used the same two positive and two negative control sera each time.

\section{Statistical analyses}

To analyze the antibody response, mean antibody levels were compared using analysis of variance (ANOVA) $(p<0.01)$ and, when the means of the two groups differed significantly, the Student-Newman-Keuls test was performed for pairwise comparisons. All analyses were carried out using MedCalc ${ }^{\circledR}$ version 8.0.0.0. The graphics were drawn in GraphPad Prism ${ }^{\circledR}$ 5 , version 5.01 .

\section{Results}

\section{DNA extraction, amplification, and cloning}

The total DNA from the E. canis strain Jaboticabal was successfully extracted and its concentration was $50 \mathrm{ng} / \mu \mathrm{L}$. The PCR was able to amplify an amplicon of $429 \mathrm{bp}$, corresponding to the $g p 19$ DNA sequence without the stop codon, and with the restriction sites added in the primers. The sequencing confirmed that the sequence cloned into the $\mathrm{pAE}$ vector corresponded to the $g p 19$ gene, showing that it shared $100 \%$ of its identity with the $g p 19$ gene from the E. canis São Paulo strain available from GenBank (accession number: EU118960); it was also in frame with $\mathrm{N}$-terminus polyhistidine-tag, forming the plasmid pAE-gp19 (Figure 1).

\section{Expression and purification conditions}

The expression of rGP19 was detected in 12\% SDS-PAGE and Western blotting as a $25 \mathrm{kDa}$ protein, but only one E. coli strain, BL21 (DE3) C41 (cultivated at $25^{\circ} \mathrm{C}$ for 16 hours and induced with $1 \mathrm{mM}$ of IPTG) (Figure 2) was able to express rGP19. This clone was induced to express rGP19 in a $500 \mathrm{~mL}$ culture and its pellet showed that rGP19 was soluble in the Akta Wash with urea only (Figure 2). $\mathrm{Ni}^{+}$affinity chromatography was able to purify a protein with $25 \mathrm{kDa}$ by $12 \%$ SDS-PAGE (Figure 3). This $25 \mathrm{kDa}$ protein was detected during Western blotting by the anti-His and dog anti-E. canis antibodies, confirming that the protein was rGP19 (Figure 4). The third and fourth elution fractions of the $\mathrm{Ni}^{+}$chromatograph showed a recombinant protein of $25 \mathrm{kDa}$ that was revealed in 12\% SDS-PAGE, as well during Western blotting. The concentration of the rGP19 recovered was $0.747 \mu \mathrm{g} \times \mathrm{mL}^{-1}$, totaling $0.747 \mathrm{mg} / \mathrm{L}$ of culture.

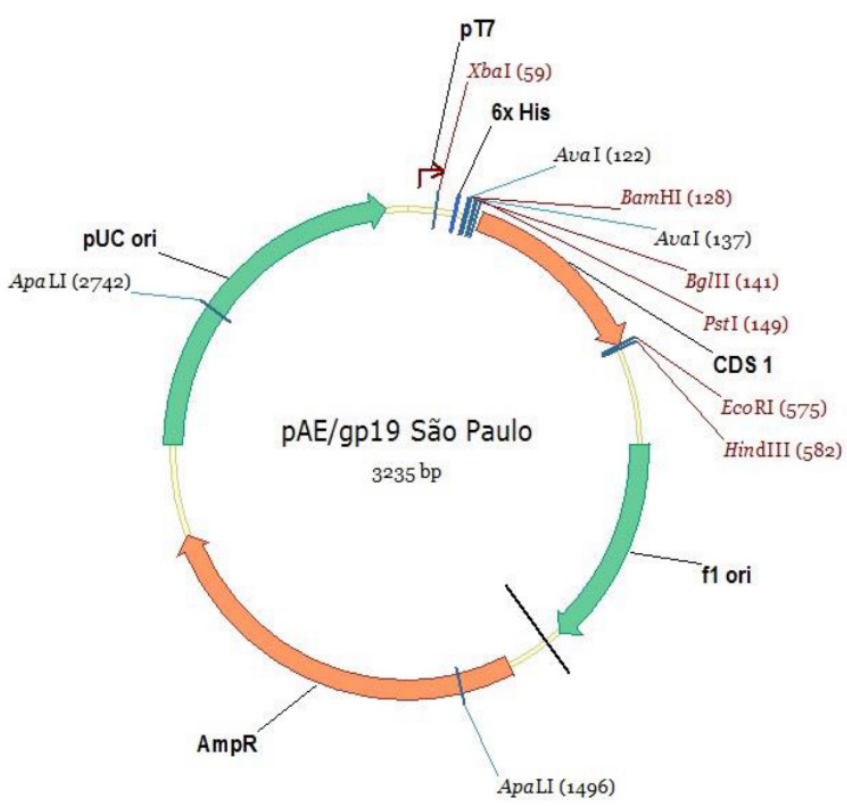

Figure 1. The plasmid pAE-gp19 with the $g p 19$ gene inserted between the KpnI and EcoRI restriction enzyme sites. 


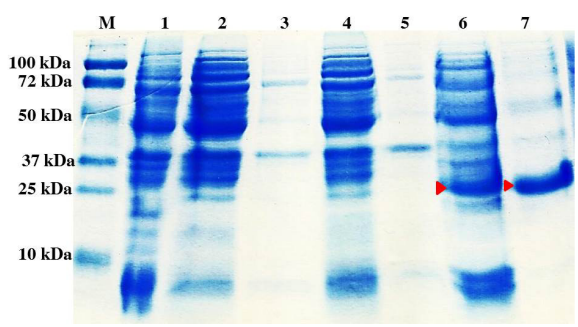

Figure 2. Solubility test for GP19. 12\% SDS-PAGE stained with Coomassie Blue. M: Molecular marker (Bio-Rad); 1: total extract sonicated; 2: pellet of the sonication with Akta Wash buffer; 3: supernatant of the sonication with Akta Wash buffer; 4: pellet of the solubilization with Akta Wash buffer with N-lauroylsarcosine; 5: supernatant of the solubilization with Akta Wash buffer with N-lauroylsarcosine; 6: pellet of the solubilization with Akta Wash buffer with urea; 7: supernatant of the solubilization with Akta Wash buffer with urea. Arrows indicate gp19.

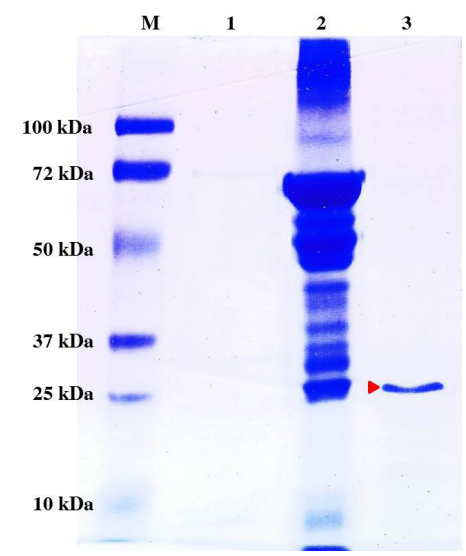

Figure 3. 12\% SDS-PAGE stained with Coomassie Blue. M: Molecular marker (Bio-Rad); 1:1 $\mu \mathrm{g}$ of polyhistidine-tag protein with $73 \mathrm{kDa}$; 2:10 $\mu \mathrm{g}$ of bovine serum albumin (BSA); $4: 3 \mu \mathrm{g}$ of purified rGP19.

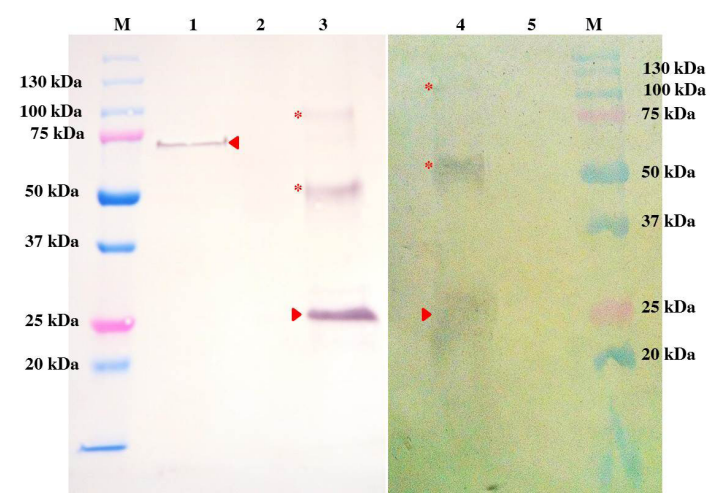

Figure 4. Western blotting. M: Molecular marker Dual Color (Bio-Rad); 1 and 5) $1 \mu \mathrm{g}$ of polyhistidine-tag protein; 2) $5 \mu \mathrm{g}$ of bovine serum albumin (BSA); 3 and 4) $3 \mu \mathrm{g}$ of purified rGP19; 1, 2, and 3) incubated with anti-His; 4 and 5) incubated with dog anti-E. canis. Arrows: rGP19 recognized by anti-His and anti-E. canis; asterisk: dimers and trimers of rGP19 recognized by anti-His and anti-E. canis.

\section{ELISA}

The ELISA showed that there was no significant difference in the relationship between $\mathrm{OD}_{492 \mathrm{~nm}}$ and the protein amount (50 ng, 100 ng, 150 ng, or 200 ng/well) (Figure 5). The lowest concentration of protein (50 ng/well) was enough to differentiate between sera that were positive or negative for CME. Regarding the serum dilution at 1:100, the $\mathrm{OD}_{492 \mathrm{~nm}}$ of the negative sera was significantly lower than that of the 1:50 dilution, and it was not different for the higher dilutions (Figure 5; p < 0.01).

The ELISA of the sera from the experimentally infected dogs was able to differentiate between the sera that were positive and negative for CME; moreover, the $\mathrm{OD}_{492 \mathrm{~nm}}$ showed a direct association with the IIFA titration. For the three sera, the ELISA graph showed a curve for the antibody, which featured a normal profile. This was in contrast to that of the IIFA titration, which showed (for dog 1) no gradual increase or gradual decrease over time; however, a higher value $(1: 40,960)$ was observed at 3, 4, and 8 weeks after infection (Figure 6). No other animals showed titers that high. Regarding dog 2, the ELISA showed a constant increase of the $\mathrm{OD}_{492 \mathrm{~nm}}$ over time, dropping at the last week alone (9 weeks after infection); the IIFA titration started to decline at week 7 following infection, with the higher titer level $(1: 20,480)$ observed at 5 and 6 weeks after infection (Figure 7). The ELISA of the serum from dog 3 showed both a gradual increase and a gradual decrease of the $\mathrm{OD}_{492 \mathrm{~nm}}$ over time, suggesting a normal profile of the antibody kinetic; the antibody peak was evident 5 weeks postinfection (Figure 8).

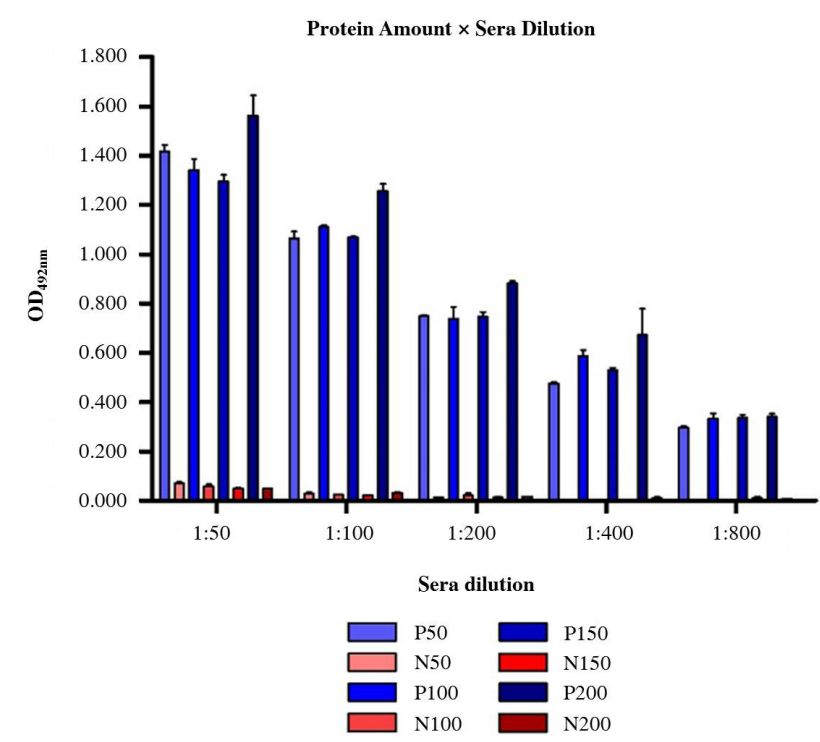

Figure 5. ELISA standardization. P50, P100, P150, and P200 are positive sera, incubated with $50,100,150$, and $200 \mathrm{ng}$ of rGP19 per well, respectively. N50, N100, N150, and N200 are negative sera, incubated with 50,100, 150, and $200 \mathrm{ng}$ of rGP19 per well, respectively. 


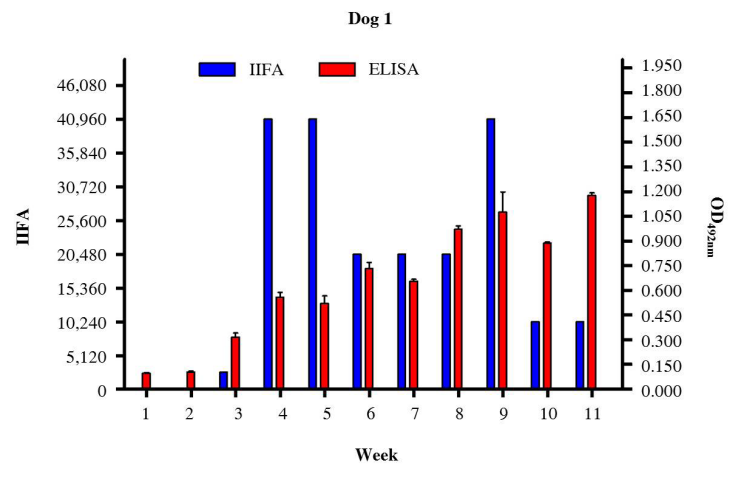

Figure 6. Comparison between the titration by IIFA of the sera collected from dog 1 and its $\mathrm{OD}_{492 \mathrm{~nm}}$ from ELISA.

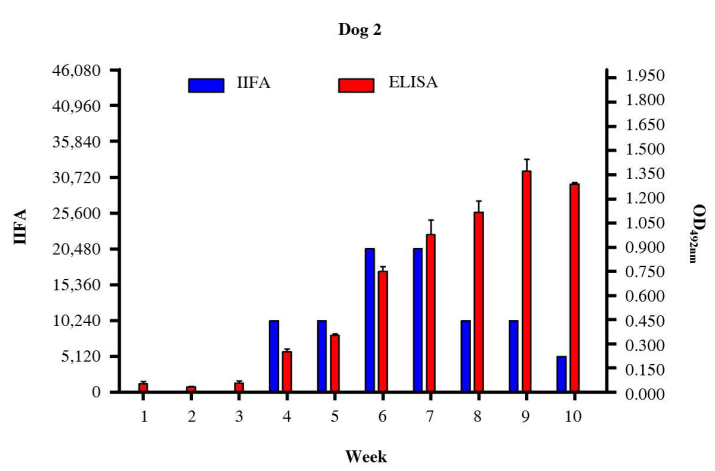

Figure 7. Comparison between the titration by IIFA of the sera collected from $\operatorname{dog} 2$ and its $\mathrm{OD}_{492 \mathrm{~nm}}$ from ELISA.

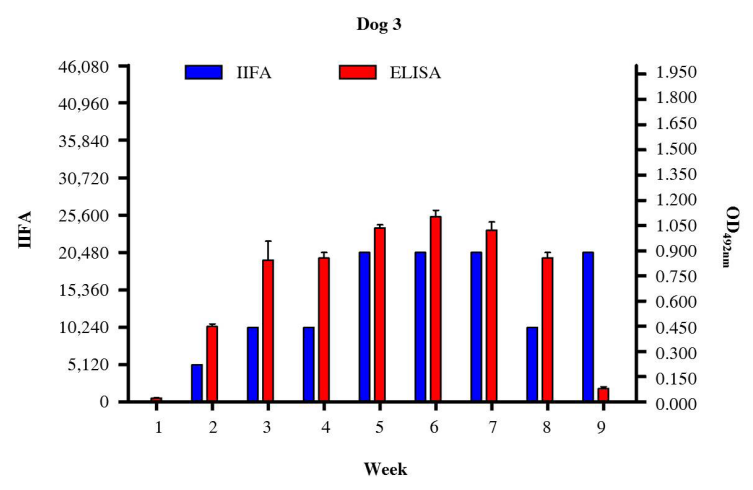

Figure 8. Comparison between the titration by IIFA of the sera collected from $\operatorname{dog} 3$ and its $\mathrm{OD}_{492 \mathrm{~nm}}$ from ELISA.

\section{Discussion}

Of the E. canis immunodominant antigens, gp19 is the most frequently conserved antigen from different geographical regions. Zhang et al. (2008) compared the sequences of nucleotides and amino acids of gp19 in strains obtained from the United States,
Brazil, and Israel, and demonstrated that they are identical. Two years later, it was shown that gp19 from the United States, Brazil, Venezuela, Greece, Italy, Turkey, and Thailand are also identical (sharing 100\% identity) (HSIEH et al., 2010). This high degree of overall nucleic acid and amino acid conservation observed in gp19 (sharing $97.8 \%-100 \%$ and $98.4 \%-100 \%$ identities, respectively) in geographically dispersed strains means that this antigen holds promise for use in a diagnostic tool for CME (HSIEH et al., 2010). Furthermore, gp19 is a species-specific antigen that allows one to distinguish between the sera from dogs infected with $E$. canis and the sera from dogs infected with E. chaffeensis, showing a high sensitivity for the detection of early acute-phase antibodies (CÁRDENAS et al., 2007). In addition, it was also shown that anti-E. canis gp19 canine sera do not react with $E$. chaffeensis lysates in Western blotting (McBRIDE et al., 2007). All of this strengthens the idea that the gp19 antigen holds major antigenic potential, justifying the efforts of this work. In this context, the production of the gp19 antigen as a tool for CME diagnostics is justified.

During the solubility test, the gp19 antigen was able to detect a $25 \mathrm{kDa}$ protein in SDS-PAGE, and the fact that its solubility was only possible in the presence of urea leads us to conclude that the protein-formed inclusion bodies were expressed in insoluble form, necessitating a denaturing agent to solubilize the inclusion bodies within the cell. The use of the Akta Wash solution with 8M urea denatures the protein completely, interrupting the molecular interactions that provide its three-dimensional structure.

The fact that the recombinant protein had a higher molecular weight $(25 \mathrm{kDa})$ than it should have $(19 \mathrm{kDa})$ is in contrast to the same $25 \mathrm{kDa}$ protein that was achieved following $\mathrm{Ni}^{+}$ chromatograph purification, and which was recognized during Western blotting by the anti-His and anti-E. canis antibodies. In addition, given that the inserted sequence was confirmed via sequencing, this protein can be characterized as a $25 \mathrm{kDa}$ protein expressed in E. coli C41. The dog sera that were positive for CME reacted with the protein during Western blotting without any unspecific reactions, and the negative sera did not react, which is characteristic of its identity. This means that rGP19 could be expressed in E. coli, even in small amounts $\left(0.747 \mathrm{mg} \times \mathrm{L}^{-1}\right)$, and that its antigenic determinants were maintained; as such, rGP19 can be used as an antigen in a diagnostic tool.

The expression of rGP19 in E. coli was cumbersome since it was difficult to express, prompting the need to use a protocol that was different from standard $\left(16\right.$ hours at $\left.25^{\circ} \mathrm{C}\right)$. From the expression of proteins by BL21 (DE3), two mutant host strains (C41 [DE3] and $\mathrm{C} 43$ [DE3]) were selected, which grew to a high saturation density; they continued to produce proteins at an elevated level without toxic effects (MIROUX \& WALKER, 1996). The toxicity was observed in 50\% of cases for C41 (DE3) and only in 4\% of cases for C43 (DE3). However, it should be pointed out that even when toxicity existed in C41 (DE3), the target protein was well overexpressed (DUMON-SEIGNOVERT et al., 2004). In this study, we identified that the C41 strain and its conditions were necessary to efficiently express and characterize rGP19.

ELISA was performed to assess the potential of rGP19 as an antigen for a diagnostic test. The best concentration of the protein was shown to be $50 \mathrm{ng} /$ well. Lower amounts of rGP19 were not 
tested because this concentration ( $50 \mathrm{ng} /$ well) was regarded as the lowest possible limit where we still had good control over protein dilution; moreover, in a previous study, ELISA was performed using a concentration of $60 \mathrm{ng} /$ well (CÁRDENAS et al., 2007). In relation to the sera dilution, the lowest dilution of 1:100 was chosen since it had a higher probability of detecting the anti-E. canis antibodies; it also featured the lowest background reaction with the negative sera.

The sera from three dogs that were experimentally infected with $E$. canis, previously titrated by IIFA, were evaluated using ELISA. It was found that rGP19 exhibited antigenic potential, as expected, since it could differentiate between the sera that were positive or negative for CME (Figure 9). The rGP19 exhibited $100 \%$ specificity during ELISA when compared to the results of the IIFA that was performed with the sera obtained from these dogs. The antibodies in the dog sera reacted at the same time in both IIFA and ELISA. Dog 1 antibodies reacted 2 weeks postinfection, $\operatorname{dog} 2$ antibodies reacted 3 weeks postinfection, and $\operatorname{dog} 3$ antibodies reacted 1 week postinfection. This means that there was a positive correlation between the results of the two immunoassays.

When comparing the two immunoassays, the ELISA curve showed a more conceivable pattern of change in the antibodies than that of the IIFA over the weeks. The variation in the titration values detected by IIFA varied from one week to another, with decreasing titers observed during the same week when we detected a high ELISA reading $\left(\mathrm{OD}_{492 \mathrm{~nm}}\right)$; these results are shown in Figure 6 for $\operatorname{dog} 1$ at weeks 6,7 , and 8 , and in Figure 8 for $\operatorname{dog} 3$ at week 8. With the exception of these cases, the results of the ELISA corresponded to the titration by IIFA in the remaining weeks.

In a previous study with $E$. canis recombinant antigens, p28 demonstrated low specificity $(-60 \%)$ for the detection of antibodies in dog sera. The antigens gp36, gp19 and GP200 showed 100\% specificity. However, gp200 showed reactivity later, 28 to 35 days after infection (CÁRDENAS et al., 2007). At the same study, the earliest detection was 2 weeks post infection by the gp36 recombinant protein, by both Western immunoblotting and ELISA, and the earliest reactivity of gp19 was achieved 2 weeks post infection (in 1 of 3 dogs), but 2 of 3 dogs reacted 21 days post infection by immunoblotting. The same three dogs had reactivity 21 days post

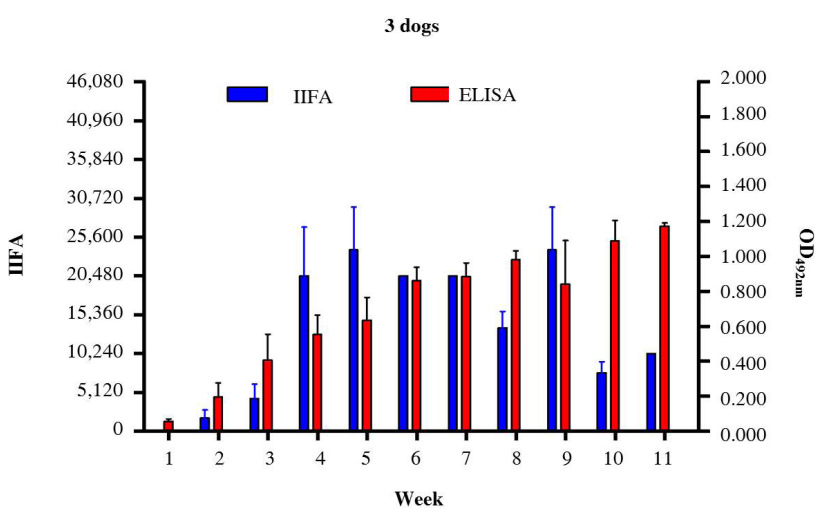

Figure 9. Comparison between the titration by IIFA of the sera collected from the three dogs and their $\mathrm{OD}_{492 \mathrm{~nm}}$ from ELISA. infection by ELISA (CÁRDENAS et al., 2007). In contrast with our study, considering that we used different conditions, from the canine infection until the ELISA development, we had a better optimization, coming to detect anti-gp 19 antibodies 1 week post infection (in 1 of 3 dogs). This result can be explained by the fact that we used a different expression and purification system and we optimized the amount of antigens for the ELISA, for example.

Considering that the acute stage of the CME occurs 8-20 days after infection and lasts 2-4 weeks (HARRUS et al., 1996), the ELISA performed with rGP19, as presented here, allows for the diagnosis of CME during the acute stage of infection - from the first week to the third week (Figures 6,7, and 8). Early diagnosis is very important for treatment, as doxycycline can be started as soon as possible, ultimately leading to a favorable prognosis.

\section{Conclusion}

In Brazil, an immunodiagnostics tool capable of detecting antibodies during the early acute phase of infection in dogs is still commercially unavailable. Now that the protein has been characterized, the next step is to develop an ELISA for the diagnosis of CME, as well as to test its specificity and sensitivity in the sera of animals that are naturally infected.

\section{Acknowledgements}

CAPES, CNPq and Fapergs. Special thanks to the Laboratório de Imunologia Aplicada à Sanidade Animal of the CBiot UFRGS, for their cooperation and support in this important work. English-language editing of this manuscript was provided by Journal Prep.

\section{References}

Aguiar DM, Hagiwara MK, Labruna MB. In vitro isolation and molecular characterization of an Ehrlichia canis strain from São Paulo, Brazil. Braz J Microbiol 2008; 39(3): 489-493. http://dx.doi.org/10.1590/S151783822008000300014 . PMid:24031251.

Baneth G, Waner T, Koplah A, Weinstein S, Keysary A. Survey of Ehrlichia canis antibodies among dogs in Israel. Vet Rec 1996; 138(11): 257-259. http://dx.doi.org/10.1136/vr.138.11.257. PMid:8734508.

Bélanger M, Sorenson HL, France MK, Bowie MV, Barbet AF, Breitschwerdt $\mathrm{EB}$, et al. Comparison of serological detection methods for diagnosis of Ehrlichia canis infections in dogs. J Clin Microbiol 2002; 40(9): 3506-3508. http://dx.doi.org/10.1128/JCM.40.9.3506-3508.2002. PMid:12202605.

Botros BA, Elmolla MS, Salib AW, Calamaio CA, Dasch GA, Arthur RR. Canine ehrlichiosis in Egypt: sero-epidemiological survey. Onderstepoort $J$ Vet Res 1995; 62(1): 41-43. PMid:8539033.

Brouqui P, Davoust B, Haddad S, Vidor E, Raoult D. Serological evaluation of Ehrlichia canis infections in military dogs in Africa and Reunion Island. Vet Microbiol 1991; 26(1-2): 103-105. http://dx.doi. org/10.1016/0378-1135(91)90046-I. PMid:2024432.

Cadman HF, Kelly PJ, Matthewman LA, Zhou R, Mason PR. Comparison of the dot-blot enzyme linked immunoassay with immunofluorescence 
for detecting antibodies to Ehrlichia canis. Vet Rec 1994; 135(15): 362. http://dx.doi.org/10.1136/vr.135.15.362. PMid:7846828.

Cárdenas AM, Doyle CK, Zhang X, Nethery K, Corstvet RE, Walker $\mathrm{DH}$, et al. Enzyme-linked immunosorbent assay with conserved immunoreactive glycoproteins gp36 and gp 19 has enhanced sensitivity and provides species-specific immunodiagnosis of Ehrlichia canis infection. Clin Vaccine Immunol 2007; 14(2): 123-128. http://dx.doi.org/10.1128/ CVI.00361-06. PMid:17151186.

Cohn LA. Ehrlichiosis and related infections. Vet Clin North Am Small Anim Pract 2003; 33(4): 863-884. http://dx.doi.org/10.1016/S01955616(03)00031-7. PMid:12910747.

Dagnone AS, Morais HS, Vidotto MC, Jojima FS, Vidotto O. Ehrlichiosis in anemic, thrombocytopenic, or tick-infested dogs from a hospital population in South Brazil. Vet Parasitol 2003; 117(4): 285-290. http:// dx.doi.org/10.1016/j.vetpar.2003.10.001. PMid:14637030.

Doyle CK, Nethery KA, Popov VL, McBride JW. Differentially expressed and secreted major immunoreactive protein orthologs of Ehrlichia canis and $E$. chaffeensis elicit early antibody responses to epitopes on glycosylated tandem repeats. Infect Immun 2006; 74(1): 711-720. http://dx.doi. org/10.1128/IAI.74.1.711-720.2006. PMid:16369028.

Dumon-Seignovert L, Cariot G, Vuillard L. The toxicity of recombinant proteins in Escherichia coli: a comparison of overexpression in BL21(DE3), C41(DE3), and C43(DE3). Protein Expr Purif 2004; 37(1): 203-206. http://dx.doi.org/10.1016/j.pep.2004.04.025. PMid:15294299.

Ferreira RF, Cerqueira AM, Castro TX, Ferreira EO, Neves FP, Barbosa AV, et al. Genetic diversity of Ehrlichia canis strains from naturally infected dogs in Rio de Janeiro, Brazil. Rev Bras Parasitol Vet 2014; 23(3): 301308. http://dx.doi.org/10.1590/S1984-29612014055. PMid:25271448.

Harrus S, Waner T, Weiss DJ, Keysary A, Bark H. Kinetics of serum antiplatelet antibodies in experimental acute canine ehrlichiosis. Vet Immunol Immunopathol 1996; 51(1-2): 13-20. http://dx.doi.org/10.1016/01652427(95)05516-9. PMid:8797272.

Hsieh YC, Lee CC, Tsang CL, Chung YT. Detection and characterization of four novel genotypes of Ehrlichia canis from dogs. Vet Microbiol 2010; 146(1-2): 70-75. http://dx.doi.org/10.1016/j.vetmic.2010.04.013. PMid:20451333.

Huxsoll DL, Hildebrandt PK, Nims RM, Amyx HL, Ferguson JA. Epizootiology of tropical canine pancytopenia. J Wildl Dis 1970; 6(4): 220-225. http://dx.doi.org/10.7589/0090-3558-6.4.220. PMid:16512116.

Labarthe N, Campos Pereira M, Barbarini O, McKee W, Coimbra CA, Hoskins J. Serologic prevalence of Dirofilaria immitis, Ehrlichia canis, and Borrelia burgdorferi infections in Brazil. Vet Ther 2003; 4(1): 67-75. PMid:12756637.

McBride JW, Comer JE, Walker DH. Novel Immunoreactive glycoprotein orthologs of Ehrlichia spp. Ann N Y Acad Sci 2003; 990(1): 678-684. http://dx.doi.org/10.1111/j.1749-6632.2003.tb07443.x. PMid:12860706.

McBride JW, Doyle CK, Zhang X, Cardenas AM, Popov VL, Nethery $\mathrm{KA}$, et al. Identification of a glycosylated Ehrlichia canis 19-kilodalton major immunoreactive protein with a species-specific serine-rich glycopeptide epitope. Infect Immun 2007; 75(1): 74-82. http://dx.doi.org/10.1128/ IAI.01494-06. PMid:17088359.
Miroux B, Walker JE. Over-production of proteins in Escherichia coli: mutant hosts that allow synthesis of some membrane proteins and globular proteins at high levels. J Mol Biol 1996; 260(3): 289-298. http://dx.doi. org/10.1006/jmbi.1996.0399. PMid:8757792.

Moraes-Filho J. Competência vetorial de carrapatos do grupo Rhipicephalus sanguineus do Brazil, Argentina e Uruguai para a transmissáo da bactéria Ehrlichia canis, agente etiológico da erliquiose monocítica canina [Thesis]. São Paulo: Universidade de São Paulo; 2013.

Murphy GL, Ewing SA, Whitworth LC, Fox JC, Kocan AA. A molecular and serologic survey of Ehrlichia canis, E. chaffeensis, and E. ewingii in dogs and ticks from Oklahoma. Vet Parasitol 1998; 79(4): 325-339. http://dx.doi.org/10.1016/S0304-4017(98)00179-4. PMid:9831955.

Nakaghi ACH, Machado RZ, Ferro JA, Labruna MB, Chryssafidis AL, André MR, et al. Sensitivity evaluation of a single-step PCR assay using Ehrlichia canis $p 28$ gene as a target and its application in diagnosis of canine ehrlichiosis. Rev Bras Parasitol Vet 2010; 19(2): 75-79. http:// dx.doi.org/10.4322/rbpv.01902001. PMid:20624341.

Parzy D, Davoust B, Raphenon G, Vidor E. Canine ehrlichiosis in Senegal: human and canine seroepidemiological survey in Dakar. Med Trop (Mars) 1991; 51(1): 59-63. PMid:2072850.

Pusterla N, Pusterla JB, Deplazes P, Wolfensberger C, Müller W, Hörauf A, et al. Seroprevalence of Ehrlichia canis and of canine granulocytic Ehrlichia infection in dogs in Switzerland. J Clin Microbiol 1998; 36(12): 3460-3462. PMid:9817854.

Rikihisa Y. The tribe Ehrlichieae and ehrlichial diseases. Clin Microbiol Rev 1991; 4(3): 286-308. PMid:1889044.

Sainz A, Tesouro MA, Rodriguez F, Mayoral I, Mazzuchelli F. Seroprevalence of Ehrlichia canis infections in police dogs in Spain. Prev Vet Med 1995; 23(3-4): 179-182. http://dx.doi.org/10.1016/0167-5877(94)00440-T.

Saito TB, Cunha-Filho NA, Pacheco RC, Ferreira F, Pappen FG, Farias NAR, et al. Canine infection by rickettsiae and ehrlichiae in southern Brazil. Am J Trop Med Hyg 2008; 79(1): 102-108. PMid:18606772.

Silva JN, Almeida AB, Boa Sorte EC, Freitas AG, Santos LGF, Aguiar DM, et al. Seroprevalence anti-Ehrlichia canis antibodies in dogs of Cuiabá, Mato Grosso. Rev Bras Parasitol Vet 2010; 19(2): 108-111. http://dx.doi. org/10.4322/rbpv.01902008. PMid:20624348.

Vieira RFC, Biondo AW, Guimarães AM, Santos AP, Santos RP, Dutra LH, et al. Ehrlichiosis in Brazil. Rev Bras Parasitol Vet 2011; 20(1): 1-12. http://dx.doi.org/10.1590/S1984-29612011000100002. PMid:21439224.

Waner T, Strenger C, Keysary A, Harrus S. Kinetics of serologic crossreactions between Ehrlichia canis and the Ehrlichia phagocytophila genogroups in experimental E. canis infection in dogs. Vet Immunol Immunopathol 1998; 66(3-4): 237-243. http://dx.doi.org/10.1016/ S0165-2427(98)00198-6. PMid:9880101.

Woody BJ, Hoskins JD. Ehrlichial diseases of dogs. Vet Clin North Am Small Anim Pract 1991; 21(1): 75-98. http://dx.doi.org/10.1016/S01955616(91)50009-7. PMid:2014630.

Zhang X, Luo T, Keysary A, Baneth G, Miyashiro S, Strenger C, et al. Genetic and antigenic diversities of major immunoreactive proteins in globally distributed Ehrlichia canis strains. Clin Vaccine Immunol 2008; 15(7): 1080-1088. http://dx.doi.org/10.1128/CVI.00482-07. PMid:18480237. 